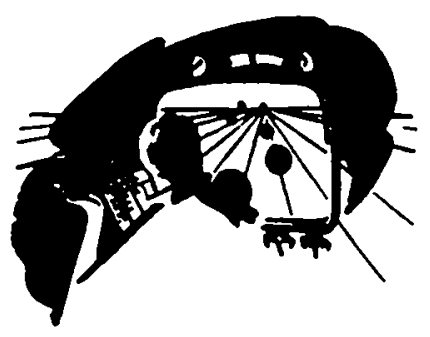

\title{
RESEARCH ABSTRACTS
}

\section{TELEVISION}

DOWELL, ERNEST C. An Experiment in Training by Television. Project 53-32. Training Analysis and Development, 3380th Technical Training Group, Keesler Air Force Base, 16 p. February 1954.

Purpose: The purpose of this research was to evaluate the efiectivenens of closed circuit television as provided by a mobile television unit to teach electronics in comparison with conventional methods of presentation. Additionally it was desired to make kinephoto recordings suitable for use as training flms in specific courses.

Procedure: Using professional personnel of a video squadron and a mobile television facility, three lessons on electronics were taught to 127 trainees. A control group was selected from subsequent classes. Instructors taught both experimental and control groups. All academic departments were requested to examine their needs for training films and prepare plans for producing the filnus.

Results: Equal results were obtained by the matched groups of students who received training by the same instructors but by different methods. Considerably more trained personnel were required to teach by the television method. A good instructor was found to be good before television cameras.

Fifty-two kine recordings were prepared. Many of the recordings could normally be jutified only on the basis of providing a means for supplementing instruction when there is a shortage of competent instructors. Under the conditions of using a mobile television unit it was concluded that practical limitations are such that the use of live television in technical training cannot be justified on the basis of providing more economical mass training. -L. Twyford

CARPENTER, C. R., and GREENHILL, L. P. An Investigation of Closed-Circuit Television for Teaching University Courses. Project Number One, Research by the Instructional Film Research Program, Pennsylvania State University, University Park, Pennsylvania. $102 \mathrm{p}$. July $31,1955$. 